\title{
Graphene Oxide as a Carrier for Drug Delivery of Methotrexate
}

\author{
Hani Nasser Abdelhamid 1,*(D), Kamal Hany Hussein 2(D) \\ 1 Advanced Multifunctional Materials Laboratory, Department of Chemistry, Faculty of Science, Assiut University, Assiut, \\ Egypt \\ 2 Department of Animal Surgery, Anaesthesia, and Radiology, Faculty of Veterinary Medicine, Assiut University, Assiut \\ 71526, Egypt., Faculty of Veterinary Medicine, Assiut University, Assiut, Egypt \\ * Correspondence: hany.abdelhamid@aun.edu.eg (H.N.A.);
}

Scopus Author ID 55370888300

Received: 2.02.2021; Revised: 10.03.2021; Accepted: 14.03.2021; Published: 31.03.2021

\begin{abstract}
Nanomaterials, including carbon-based nanoparticles, have been applied as carriers for anticancer drugs. This short communication reported the synthesis, cytotoxicity, and drug delivery of methotrexate using graphene oxide (GO) as a carrier. GO was synthesized following Hummer's method. It was characterized using X-ray diffraction (XRD), transmission electron microscope (TEM), and scanning electron microscope (SEM). Data analysis confirms the synthesis of GO with high crystallinity and lamellae morphology. GO showed a high cytocompatibility toward the human EA.hy926 endothelial cells. GO has been used as a carrier for the anticancer drug; methotrexate. The drug delivery was tested for hepatocellular carcinoma cells (HepG2 cells), human embryonic kidney cells (HEK293A cells), and porcine skin fibroblasts (PEF).
\end{abstract}

Keywords: carbon nanomaterials; drug delivery; chemotherapy; methotrexate.

(C) 2021 by the authors. This article is an open-access article distributed under the terms and conditions of the Creative Commons Attribution (CC BY) license (https://creativecommons.org/licenses/by/4.0/).

\section{Introduction}

Cancer disease has been considered a severe threat to humans. The World Health Organization (WHO, 2018) reported that cancer causes one in six deaths. According to a study in 2020, there are 19 million cases related to cancer annually [1], causing 8.8 million deaths (represents $15.7 \%$ of deaths annually) [2,3]. Several drugs have been reported as promising anticancer therapeutics [4-11]. However, they lack high cell internalization, cell permeation, bioavailability, selectivity, and increased efficiencies [5,6,12-19]. Thus, several carriers, including natural polymers [20], polysaccharides [13], magnetic carriers [21], and extracellular vehicles (EVs)[22], were reported for drug delivery. They exhibit high drug loading capability, controlled release, and increased cell internalization. Nanotechnology has advanced biomedical fields, including cancer treatment [23-29].

Graphene is a new allotrope (two-dimensional, 2D) of carbon nanomaterials with a single layer of $s p^{2}$-hybridized carbon atoms [30-39]. The synthesis of graphene was awarded Nobel Prize in Chemistry in 2010. Graphene-based nanomaterials such as graphene oxide(GO) have advanced biomedicine, including drug delivery [40,42]. They can proceed into scaffold $[43,45]$, fiber [46], and hydrogels [47]. Graphene-based materials offered several advantages, including high drug loading and release abilities [47]. Mixed anticancer drugs such as doxorubicin (DOX) and camptothecin (CPT) can be loaded into GO [49]. Thus, they can deliver more than one drug simultaneously. The drug can be loaded to graphene via covalent 
through cross-linking chemistry [50], electrostatic, and physical absorption interactions such as $\pi-\pi$ cooperative interaction [51]. The drug delivery can be controlled via $\mathrm{pH}[50,52]$, enzymatic [53], Near-infrared (NIR) light [54], and electrically control [55]. The surface modification ensures high drug release [56]. Graphene can also be modified with other nanoparticles, including magnetic nanoparticles for photothermal treatment [57]. Graphenebased materials offer multifunctionality [58-61]. The polar groups render the material highly hydrophilic. Thus, they were used as a carrier for the delivery of anticancer drugs such as DOX [62], quercetin and gefitinib [63], sumatriptan succinate (SS)[64], and cytarabine (CYT)[65].

Herein, the application of graphene oxide (GO) to deliver methotrexate (MTX) was investigated. Hummer's method was followed to synthesis GO followed by ultrasonication to ensure high dispersion. The crystallinity and morphology of GO were characterized using Xray diffraction (XRD) and electron microscope (transmission (TEM), scanning (SEM)). The material was mixed with methotrexate. Methotrexate-loaded GO was tested using hepatocellular carcinoma cells (HepG2 cells), human embryonic kidney cells (HEK293A cells), and porcine skin fibroblasts (PEF).

\section{Materials and Methods}

Graphite flakes were purchased from Alfa Aeser (Germany). 3-[4,5dimethylthiazol-2-yl]-2,5-diphenyltetrazolium bromide (MTT), sulfuric acid, and potassium permanganate $\left(\mathrm{KMnO}_{4}\right)$ were purchased from Sigma-Aldrich (USA).

\subsection{Synthesis of $G O$.}

GO was prepared using Hummer's method [32,66]. Natural graphite $(1.0 \mathrm{~g})$ was dispersed into a mixture of sulfuric acid $(15.0 \mathrm{~mL})$ and nitric acid $(10.0 \mathrm{~mL})$ in an ice-bath. Potassium permanganate $(3.0 \mathrm{~g})$ was gradually added to the acid mixture during stirring. After $12 \mathrm{~h}$, hydrogen peroxide $(15.0 \mathrm{~mL})$ was dropped. $\mathrm{GO}$ was collected and washed with $\mathrm{HCl}$ and water to remove any impurities. The solution of $\mathrm{GO}(1 \mathrm{mg} / \mathrm{mL})$ was prepared via ultrasonication $(140 \mathrm{~W})$ for $2 \mathrm{~d}$ at $60{ }^{\circ} \mathrm{C}$.

\subsection{Instruments.}

X-ray diffraction (XRD) was recorded using a PANalytical X'Pert Pro diffractometer $(\mathrm{Cu} \mathrm{K} \alpha 1, \lambda$ of $1.54 \AA$ ). Transmission electron microscopy (TEM) image was captured using a JEM-2100 instrument (JEOL, Japan). Scanning electron microscopy (SEM) image was performed using a JSM-7000 instrument (JEOL). UV-Vis spectra were recorded using Thermo Scientific Evolution-300. Fourier transform infrared (FT-IR) spectra were evaluated in solid form using Shimadzu-470 via the $\mathrm{KBr}$ disc technique.

\subsection{Indirect cytotoxicity assay.}

Human EA.hy926 endothelial cells were cultured in Dulbecco's modified Eagle medium (DMEM; Invitrogen, USA) supplemented with $10 \%$ fetal bovine serum (FBS; Hyclone, USA) and $1 \%$ penicillin/streptomycin (p/s, Gibco, USA) in a humidified incubator at $37^{\circ} \mathrm{C}$ and $5 \% \mathrm{CO}_{2}$. The cells were harvested using the trypsin-based method. Extracts were prepared from the GO to investigate any potential toxicological risk. The substrate was sterilized using ethylene oxide gas and mixed with serum-free DMEM supplemented with $1 \%$ $\mathrm{p} / \mathrm{s}$ culture medium under the condition of $37^{\circ} \mathrm{C} / 120 \mathrm{r} / \mathrm{min}$ for $72 \mathrm{~h}$, according to a ratio 
standard of $0.2 \mathrm{~g} / \mathrm{mL}$ of culture medium [67]. Then, the supernatant was centrifuged and filtered to prepare the preconditioned media finally.

Cells were cultured at a density of $5 \times 10^{4}$ cells/well in 24 well-plates for $24 \mathrm{~h}$ using a complete culture medium. The medium was aspirated, then $500 \mu \mathrm{L}$ of conditioned or control medium was added after combining 10\% FBS. As a negative control, cells were cultured with DMEM, while in the positive control wells, the cells were cultured in the presence of $20 \%$ dimethyl sulfoxide (DMSO). Cell viability was qualitatively investigated on day 3 using a Live/Dead assay kit (calcein-AM/ethidium Bromide homodimer, Invitrogen), according to the manufacturer's instructions, being viewed under a fluorescence microscope (Olympus, Japan).

\subsection{Drug loading.}

The anticancer drug was loaded by adding $1.0 \mathrm{~mL}$ of methotrexate $(100 \mu \mathrm{g} / \mathrm{mL}$; SigmaAldrich) to $4.0 \mathrm{~mL}$ of $\mathrm{GO}$ in buffer solution $(25 \mu \mathrm{g} / \mathrm{mL})$ under stirring for 48 hours in the dark at room temperature.

\subsection{Drug delivery testing.}

Hepatocellular carcinoma cells (HepG2 cells), human embryonic kidney cells (HEK293A cells), and porcine skin fibroblasts (PEF) were cultured in DMEM supplemented with $10 \% \mathrm{FBS}$ in a humidified $5 \% \mathrm{CO}_{2}$ atmosphere inside an incubator at $37^{\circ} \mathrm{C}$. The cells were harvested from $90 \%$ confluent cell culture plates and were resuspended in a completely fresh medium before plating. The cells $\left(3 \times 10^{4}\right)$ were seeded in a 24 -well plate. The cells were cultured for 24 hours, washed twice with phosphate-buffered saline (PBS), and then incubated with either MTX-GO, or MTX $(20 \mu \mathrm{g} / \mathrm{mL})$, or GO $(20 \mu \mathrm{g} / \mathrm{mL})$ only containing DMEM medium at $37^{\circ} \mathrm{C}$ for 24 hours. The cell viability was evaluated using the MTT assay. Active cells reduce yellow-colored MTT to purple-colored formazan dye crystals. Briefly, $50 \mu \mathrm{L}$ of MTT solution $(5 \mathrm{mg} / \mathrm{mL})$ was added to each well and incubated at $37^{\circ} \mathrm{C}$ for 4 hours. After discarding the medium containing MTT, $350 \mu \mathrm{L}$ of the cells were cultured in the presence of $20 \%$ DMSO. After 10 minutes of incubation, $100 \mu \mathrm{L}$ aliquots from the wells were pipette into another 96-well plate. The color developed was quantified by recording the absorbance at a wavelength of $570 \mathrm{~nm}$ with a spectrophotometer.

\section{Results and Discussion}

\subsection{Material characterization.}

GO was synthesized through graphite oxidation using $\mathrm{KMnO}_{4}$ in an acidic solution (Figure 1) $[39,68,69]$. XRD pattern for GO exhibits a strong Bragg's diffraction peak at $10.9^{\circ}$ corresponding to Miller index of (002) plane (Figure 2a). The d-spacing for the prepared material is $0.9 \mathrm{~nm}$ (Figure 2a). The morphology of GO was evaluated using TEM and SEM images (Figure 3). The transparency of GO in the TEM image reveals that GO consists of a few 2D layers (Figure 3a). SEM images confirm the lamellae morphology of GO (Figure 3b). The TEM and SEM images reveal that GO has crumbling morphology (Figure 3).

$\mathrm{UV}-\mathrm{Vis}$ spectrum of GO shows maximum absorption bands at $250 \mathrm{~nm}$ and $355 \mathrm{~nm}$ corresponding to $\pi \rightarrow \pi^{*}$ transition of aromatic $\mathrm{C}-\mathrm{C}$ bonds and $\mathrm{n} \rightarrow \pi^{*}$ transition of $\mathrm{C}=\mathrm{C}$ (Figure 2b) [70]. Based on the chemical structure, MTX shows strong $\pi-\pi^{*}$ or $\sigma-\sigma^{*}$ transition in the UV-Vis region at maximum absorbance of $368 \mathrm{~nm}$ and $274 \mathrm{~nm}$ (Figure $2 \mathrm{~b}$ ). The ultimate 
absorbance band of MTX at $368 \mathrm{~nm}$ was shifted to $361 \mathrm{~nm}$ after conjugation with GO indicating the strong interaction between GO and MTX.

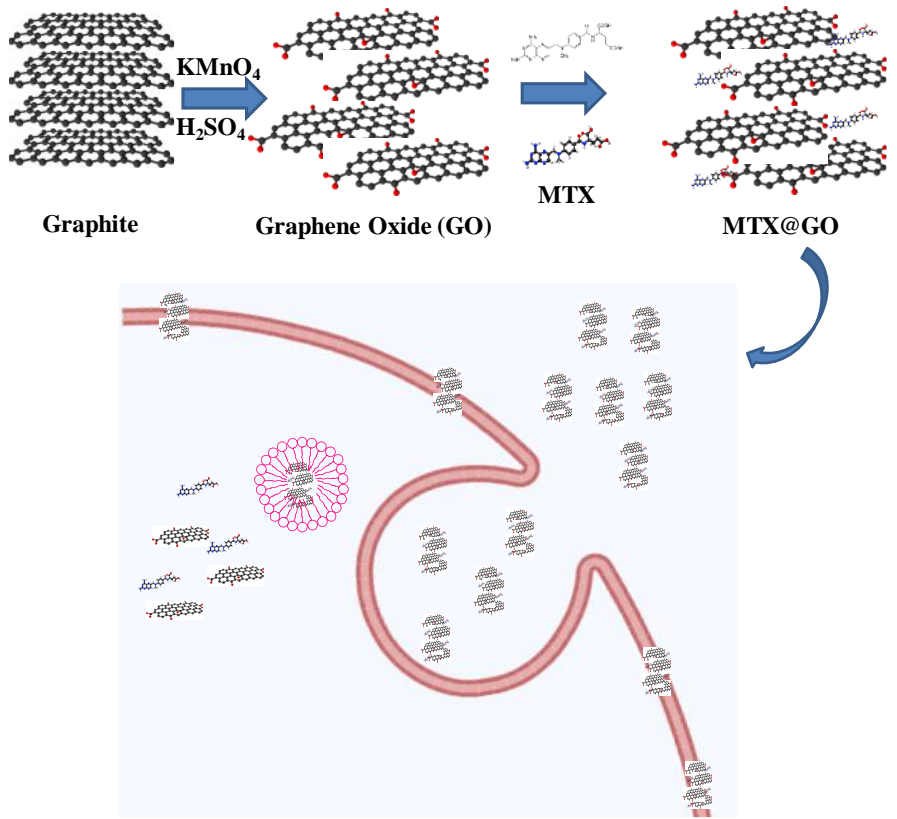

Figure 1. Schematic representation for the synthesis of GO and loading of methotrexate for drug delivery.

The chemical function groups before and after the interactions were characterized using FT-IR spectra (Figure 2c). GO exhibits vibrational bands at $3569 \mathrm{~cm}^{-1}, 1707 \mathrm{~cm}^{-1}, 1628 \mathrm{~cm}^{-1}$, $1412 \mathrm{~cm}^{-1}$, and $1029 \mathrm{~cm}^{-1}$, corresponding to $\mathrm{O}-\mathrm{H}$ stretching, $\mathrm{C}=\mathrm{O}$ stretching of the carboxylic acid groups, aromatic $\mathrm{C}-\mathrm{C}$ stretching, $\mathrm{O}-\mathrm{H}$ deformation, and the $\mathrm{C}-\mathrm{O}$ (Figure 2c). The FT-IR spectrum of MTX shows the characteristic bands at $1380 \mathrm{~cm}^{-1}, 1644 \mathrm{~cm}^{-1}$, and $3400 \mathrm{~cm}^{-1}$ corresponding to $\mathrm{C}-\mathrm{N},-\mathrm{NH}_{2}$, and $\mathrm{N}-\mathrm{H}$, respectively (Figure 2c). MTX-GO exhibits the characteristic features for both materials. However, the vibrational bands of MTX mainly disappear, indicating the strong interaction with GO (Figure 2c).
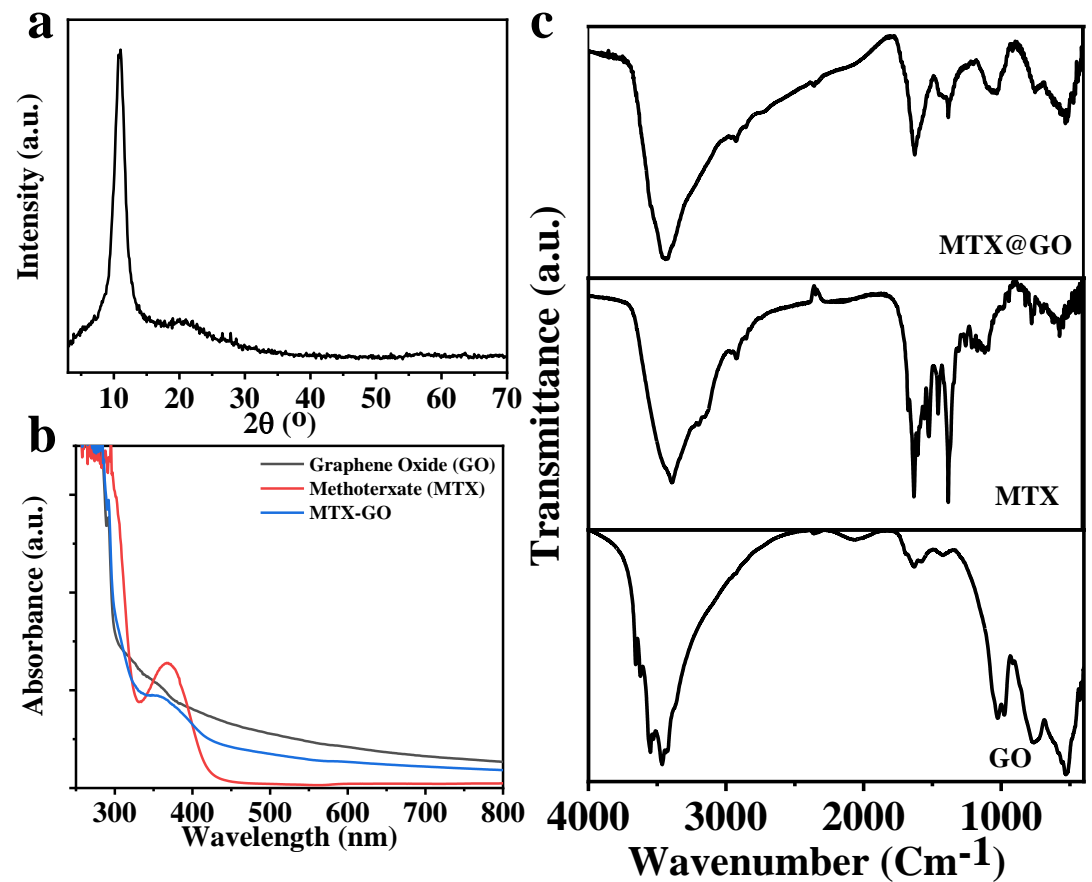

Figure 2. (a) XRD pattern of GO; (b) UV-Vis spectra for GO, MTX, and MTX-GO; (c) FT-IR spectra for GO, MTX, and MTX-GO. 


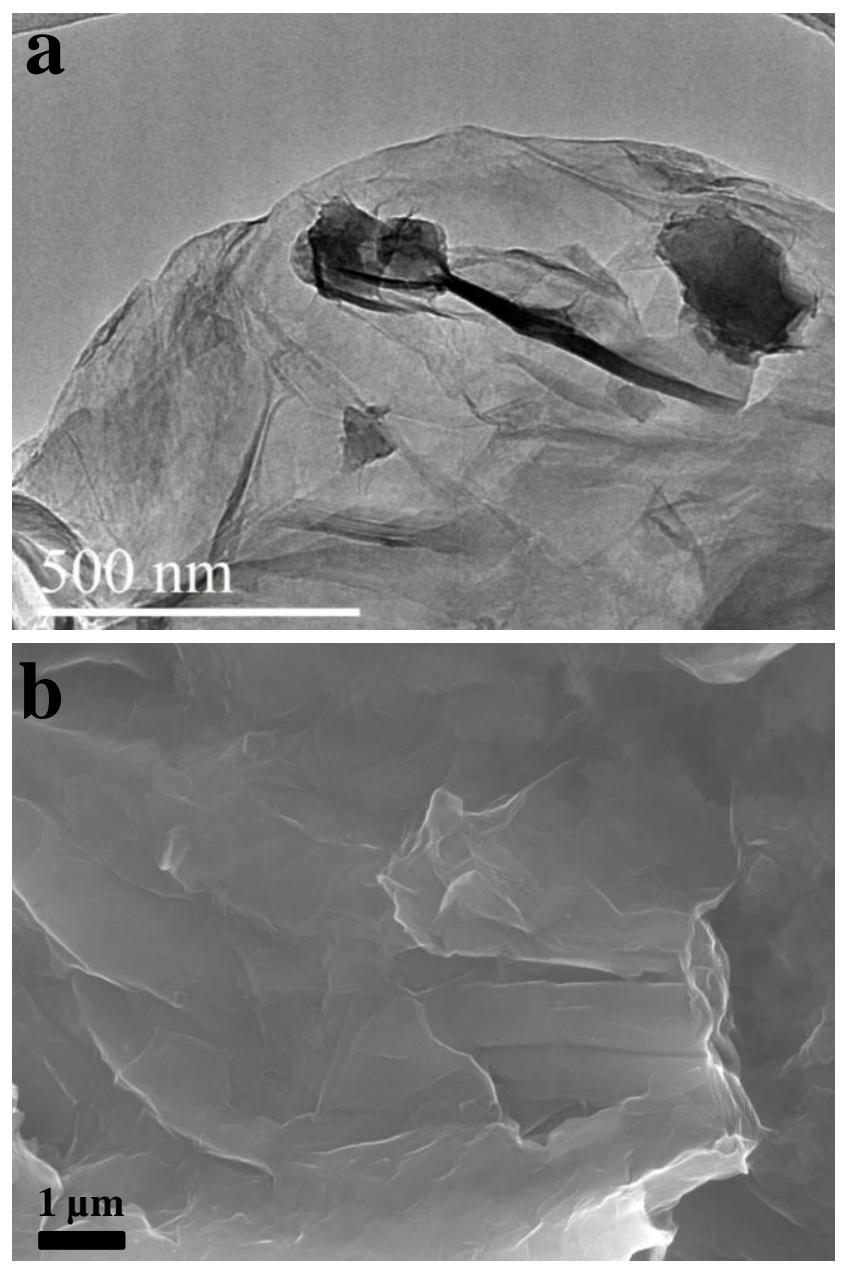

Figure 3. (a) TEM image; (b) SEM image of GO.

\subsection{GO cytocompatibility.}

The fluorescence images of EA.hy926 cells were also reported (Figure 4). Images indicate high cell density revealing the high biocompatible nature of GO (Figure 4).
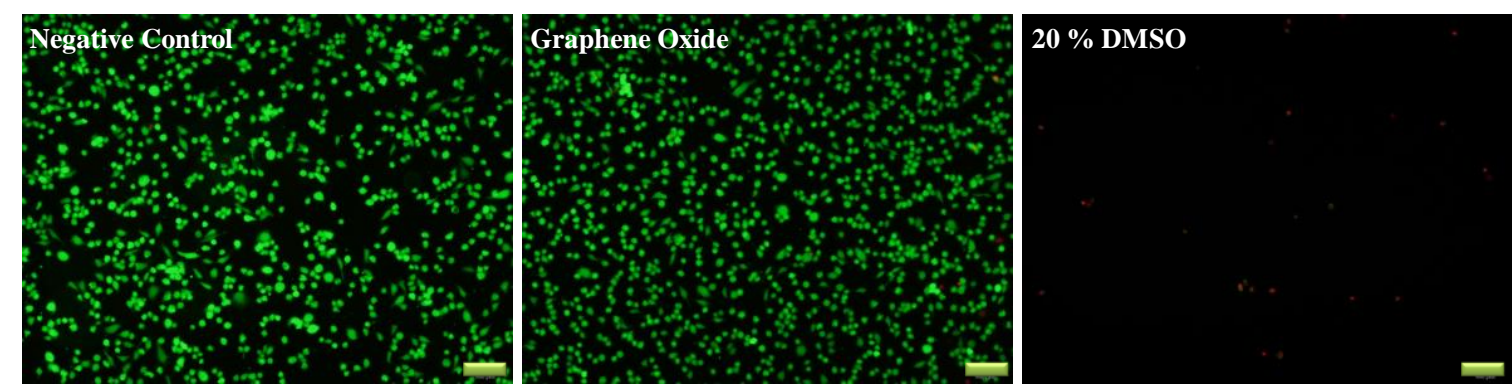

Figure 4. Fluorescence images of live cells (EA.hy926 cells) after 3 days of culture. Scale bar represents 100 $\mu \mathrm{m}$.

\subsection{Drug delivery.}

GO was used for the delivery of methotrexate (Figure 1). Both sides of GO layers can adsorb MTX via non-covalent interactions including electrostatic, and $\pi-\pi$ intercalation. The GO layers' interplanar distance is close to $1 \mathrm{~nm}$, which offers MTX intercalation between the layers. Thus, GO can be used as a carrier for the delivery of MTX. The loading of MTX onto GO was achieved by mixing both species in an aqueous solution with sonication aid. The drug release was evaluated using HepG2, HEK293A, and PEF cells. 
The MTT assay showed that the bare GO does not cause any considerable cytotoxic effect to the three cell types; HepG2, HEK293A, and PEF cells (Figure 5). The free MTX was taken up by the tumor cell line (HepG2 cells) and the normal cells (HEK293A and PEF cells) with almost similar cytotoxicity to all three cell types without apparent selectivity. After conjugating the MTX to GO as a carrier, the MTX-GO displayed significant specific cytotoxicity to the tumor cell line (HepG2 cells) compared to the normal cells (HEK293A and PEF cells). The results may open new avenues for using GO-based materials for clinical and surgery applications [71-74].

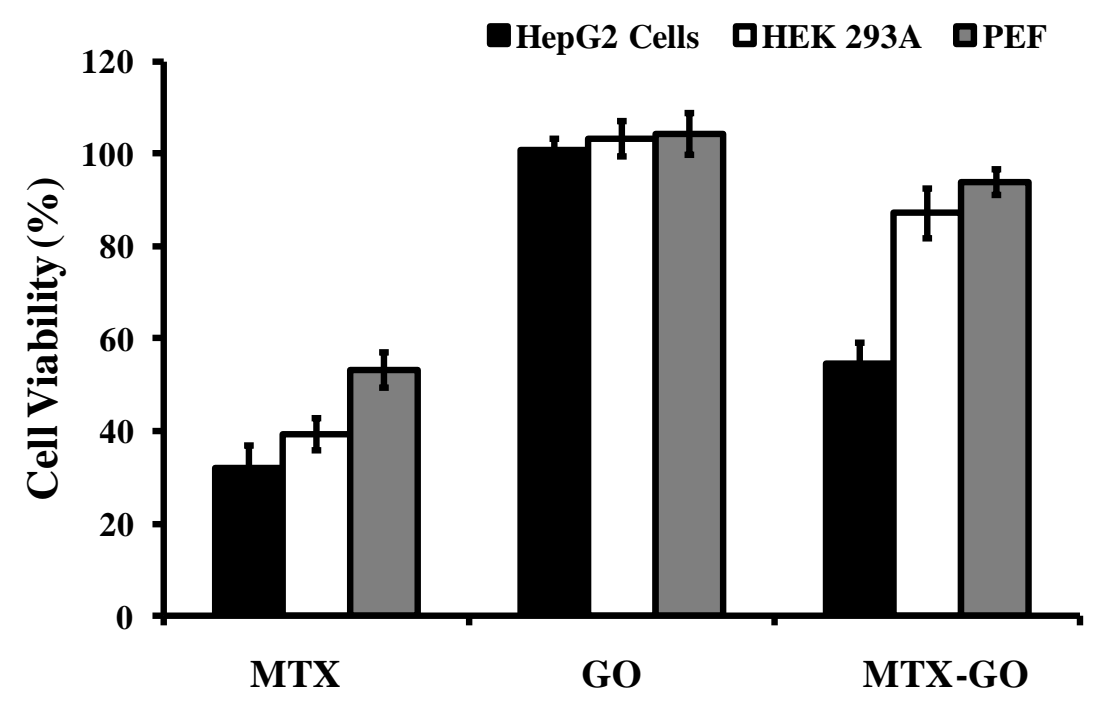

Figure 5. MTT assay for MTX, GO, and MTX-GO.

\section{Conclusions}

GO has been synthesized and applied as a carrier for the delivery of methotrexate. It exhibits high biocompatibility. The drug loading is simple. The cell viability for HepG2, HEK293A, and PEF cells showed controlled release. These findings open new opportunities for the biomedical applications of graphene oxide as a carrier for drug delivery.

\section{Funding}

This research has no funding.

\section{Acknowledgments}

This research has no acknowledgment.

\section{Conflicts of Interest}

The authors declare no conflict of interest.

\section{References}

1. Sciacovelli, M.; Schmidt, C.; Maher, E.R.; Frezza, C. Metabolic Drivers in Hereditary Cancer Syndromes. Annual Review of Cancer Biology 2020, 4, 77-97, https://doi.org/10.1146/annurev-cancerbio-030419033612.

2. Wang, H.; Naghavi, M.; Allen, C.; Barber, RM; Bhutta, Z.A.; et al.. Global, regional, and national life expectancy, all-cause mortality, and cause-specific mortality for 249 causes of death, 1980-2015: a systematic analysis for the Global Burden of Disease Study 2015. The Lancet 2016, 388, 1459-1544, 
https://doi.org/10.1016/S0140-6736(16)31012-1.

3. Abdelhamid, H.N.; Talib, A.; Wu, H.-F. One pot synthesis of gold - carbon dots nanocomposite and its application for cytosensing of metals for cancer cells. Talanta 2017, 166, 357-363, https://doi.org/10.1016/j.talanta.2016.11.030.

4. Abdelhamid, H.N.; Dowaidar, M.; Hällbrink, M.; Langel, Ü. Cell Penetrating Peptides-MOFs: An Efficient Gene Delivery Platform. Available at SSRN 3435895 2019, https://doi.org/10.2139/ssrn.3435895.

5. Abdelhamid, H.N.; Dowaidar, M.; Langel, Ü. Carbonized chitosan encapsulated hierarchical porous zeolitic imidazolate frameworks nanoparticles for gene delivery. Microporous Mesoporous Mater. 2020, 302, 110200, https://doi.org/10.1016/j.micromeso.2020.110200.

6. Abdelhamid, H.N.; Dowaidar, M.; Hällbrink, M.; Langel, Ü. Gene delivery using cell penetrating peptideszeolitic imidazolate frameworks. Microporous Mesoporous Mater. 2020, 300, 110173, https://doi.org/10.1016/j.micromeso.2020.110173.

7. Abdelhamid, HN; El-Bery, H.M.; Metwally, A.A.; Elshazly, M.; Hathout, R.M. Synthesis of CdS-modified chitosan quantum dots for the drug delivery of Sesamol. Carbohydr. Polym. 2019, 214, 90-99, https://doi.org/10.1016/j.carbpol.2019.03.024.

8. Sultan, S.; Abdelhamid, HN; Zou, X.; Mathew, A.P. CelloMOF: Nanocellulose Enabled 3D Printing of Metal-Organic Frameworks. Adv. Funct. Mater. 2019, 29, 1805372 , https://doi.org/10.1002/adfm.201805372.

9. Dowaidar, M.; Nasser Abdelhamid, H.; Hällbrink, M.; Langel, Ü.; Zou, X. Chitosan enhances gene delivery of oligonucleotide complexes with magnetic nanoparticles-cell-penetrating peptide. J. Biomater. Appl. 2018, 33, 392-401, https://doi.org/10.1177/0885328218796623.

10. Dowaidar, M.; Abdelhamid, H.N.; Hällbrink, M.; Zou, X.; Langel, Ü. Graphene oxide nanosheets in complex with cell penetrating peptides for oligonucleotides delivery. Biochim. Biophys. Acta - Gen. Subj. 2017, 1861, 2334-2341, https://doi.org/10.1016/j.bbagen.2017.07.002.

11. Dowaidar, M.; Abdelhamid, H.N.; Hällbrink, M.; Freimann, K.; Kurrikoff, K.; Zou, X.; Langel, Ü. Magnetic Nanoparticle Assisted Self-assembly of Cell Penetrating Peptides-Oligonucleotides Complexes for Gene Delivery. Sci. Rep. 2017, 7, 9159, https://doi.org/10.1038/s41598-017-09803-z.

12. Peer, D.; Karp, J.M.; Hong, S.; Farokhzad, O.C.; Margalit, R.; Langer, R. Nanocarriers as an emerging platform for cancer therapy. Nature Nanotechnology 2007, 2, 751-760, https://doi.org/10.1038/nnano.2007.387.

13. Barclay, T.G.; Day, CM; Petrovsky, N.; Garg, S. Review of polysaccharide particle-based functional drug delivery. Carbohydr. Polym. 2019, 221, 94-112, https://doi.org/10.1016/j.carbpol.2019.05.067.

14. Abdelhamid, H.N. Biointerface between ZIF-8 and biomolecules and their applications. Biointerface Res. Appl. Chem. 2021, 11, 8283-8297, https://doi.org/10.33263/BRIAC111.82838297.

15. Abdelhamid, H.N. Nanocytotoxicity using matrix-assisted laser desorption ionization mass spectrometry. Future Microbiol. 2020, 15, 385-387, https://doi.org/10.2217/fmb-2019-0260.

16. Rajendran, S.; Mukherjee, A.; Shukla, R.; Abdelhamid, H. Nanotoxicity Prevention and Antibacterial Applications of Nanomaterials; Elsevier, 2020;

17. Abdelhamid, HN Chapter 9 - General methods for detection and evaluation of nanotoxicity. In Nanotoxicity, Rajendran, S., Mukherjee, A., Nguyen, T.A., Godugu, C., Shukla, R.K., Eds. Elsevier: 2020; 195-214, https://doi.org/10.1016/B978-0-12-819943-5.00009-9.

18. Keservani, R.; Sharma, A.; Abdelhamid, H. Nanoparticulate Drug Delivery Systems; Keservani, R.K., Sharma, A.K., Eds.; CRC Press, 2019.

19. Abdelhamid, H.N.; Wu, H.-F. Nanoparticles Advance Drug Delivery for Cancer Cells. In Nanoparticulate Drug Delivery Systems; Keservani, R.K., Sharma, A.K., Eds.; Apple Academic Press: USA, 2019; pp. 121150 ISBN 978-1-77188-695-6.

20. George, A.; Shah, P.A.; Shrivastav, P.S. Natural biodegradable polymers based nano-formulations for drug delivery: A review. Int. J. Pharm. 2019, 561, 244-264, https://doi.org/10.1016/j.ijpharm.2019.03.011.

21. Liu, Y.-L.; Chen, D.; Shang, P.; Yin, D.-C. A review of magnet systems for targeted drug delivery. J. Control. Release 2019, 302, 90-104, https://doi.org/10.1016/j.jconrel.2019.03.031.

22. Gudbergsson, J.M.; Jønsson, K.; Simonsen, J.B.; Johnsen, K.B. Systematic review of targeted extracellular vesicles for drug delivery - Considerations on methodological and biological heterogeneity. J. Controlled Release 2019, 306, 108-120, https://doi.org/10.1016/j.jconrel.2019.06.006.

23. Abdelhamid, HN; Sharmoukh, W. Intrinsic catalase-mimicking MOFzyme for sensitive detection of hydrogen peroxide and ferric ions. Microchem. J. 2021, 163, 105873, https://doi.org/10.1016/j.microc.2020.105873.

24. Yousef, M.S.; Abdelhamid, H.N.; Hidalgo, M.; Fathy, R.; Gómez-Gascón, L.; Dorado, J. Antimicrobial activity of silver-carbon nanoparticles on the bacterial flora of bull semen. Theriogenology 2021, 161, 219227, https://doi:10.1016/j.theriogenology.2020.12.006.

25. Abdelhamid, H.N.; Mahmoud, G.A.-E.; Sharmouk, W. A cerium-based MOFzyme with multi-enzyme-like activity for the disruption and inhibition of fungal recolonization. Journal of Materials Chemistry B 2020, 8 , 7548-7556, https://doi.org/10.1039/D0TB00894J.

26. Zulfajri, M.; Abdelhamid, HN; Sudewi, S.; Dayalan, S.; Rasool, A.; Habib, A.; Huang, G.G. Plant Part- 
Derived Carbon Dots for Biosensing. Biosensors 2020, 10, https://doi.org/10.3390/bios10060068.

27. Sekar, K.; Hani Nasser, A.; Nazim, H.; Hui-Fen, W. Cytotoxicity of Palladium Nanoparticles Against Aspergillus Niger. Nanoscience \& Nanotechnology-Asia $\quad \mathbf{2 0 2 0}, \quad 10, \quad 80-85$, https://doi.org/10.2174/2210681208666180904113754.

28. Abdelhamid, H.N.; Wu, H.-F. Selective biosensing of Staphylococcus aureus using chitosan quantum dots. Spectrochimica Acta Part A: Molecular and Biomolecular Spectroscopy 2018, 188, 50-56, https://doi.org/10.1016/j.saa.2017.06.047.

29. Chen, Z.-Y.; Abdelhamid, H.N.; Wu, H.-F. Effect of surface capping of quantum dots (CdTe) on proteomics. Rapid Commun. Mass Spectrom. 2016, 30, 1403-1412, https://doi.org/10.1002/rcm.7575.

30. Geim, A.K.; Novoselov, K.S. The rise of graphene. Nature Materials 2007, 6, 183-191, https://doi.org/10.1038/nmat1849.

31. Abdelhamid, H.N.; Wu, H.-F. Multifunctional graphene magnetic nanosheet decorated with chitosan for highly sensitive detection of pathogenic bacteria. Journal of Materials Chemistry B 2013, 1, 3950-3961, https://doi.org/10.1039/c3tb20413h.

32. Shahnawaz Khan, M.; Abdelhamid, H.N.; Wu, H.-F. Near infrared (NIR) laser mediated surface activation of graphene oxide nanoflakes for efficient antibacterial, antifungal and wound healing treatment. Colloids Surf. B. Biointerfaces 2015, 127, 281-291, https://doi.org/10.1016/j.colsurfb.2014.12.049.

33. Abdelhamid, HN Nanoparticle assisted laser desorption/ionization mass spectrometry for small molecule analytes. Microchimica Acta 2018, 185, 200, https://doi.org/10.1007/s00604-018-2687-8.

34. Abdelhamid, H.N.; Wu, H.-F. Proteomics analysis of the mode of antibacterial action of nanoparticles and their interactions with proteins. TrAC, Trends Anal. Chem. 2015, 65, 30-46, https://doi.org/10.1016/j.trac.2014.09.010.

35. Abdelhamid, H.N.; Wu, H.-F. A method to detect metal-drug complexes and their interactions with pathogenic bacteria via graphene nanosheet assist laser desorption/ionization mass spectrometry and biosensors. Anal. Chim. Acta 2012, 751, 94-104, https://doi.org/10.1016/j.aca.2012.09.012.

36. Manikandan, M.; Nasser Abdelhamid, H.; Talib, A.; Wu, H.-F. Facile synthesis of gold nanohexagons on graphene templates in Raman spectroscopy for biosensing cancer and cancer stem cells. Biosensors Bioelectron. 2014, 55, 180-186, https://doi.org/10.1016/j.bios.2013.11.037.

37. Abdelhamid, H.N.; Khan, M.S.; Wu, H.-F. Graphene oxide as a nanocarrier for gramicidin (GOGD) for high antibacterial performance. RSC Advances 2014, 4, 50035-50046, https://doi.org/10.1039/c4ra07250b.

38. Wu, B.-S.; Abdelhamid, H.N.; Wu, H.-F. Synthesis and antibacterial activities of graphene decorated with stannous dioxide. RSC Advances 2014, 4, 3722-3731, https://doi.org/10.1039/c3ra43992e.

39. Ashour, RM; Abdelhamid, HN; Abdel-Magied, A.F.; Abdel-Khalek, A.A.; Ali, M.M.; Uheida, A.; Muhammed, M.; Zou, X.; Dutta, J. Rare Earth Ions Adsorption onto Graphene Oxide Nanosheets. Solvent Extr. Ion Exch. 2017, 35, 91-103, https://doi.org/10.1080/07366299.2017.1287509.

40. Liu, J.; Cui, L.; Losic, D. Graphene and graphene oxide as new nanocarriers for drug delivery applications. Acta Biomater. 2013, 9, 9243-9257, https://doi.org/10.1016/j.actbio.2013.08.016.

41. Muhammad, D.; Bin, L.; Wei, W. Comprehensive Review on Graphene Oxide for Use in Drug Delivery System. Curr. Med. Chem. 2020, 27, 3665-3685, https://doi.org/10.2174/13816128256661902011296290.

42. Croitoru, A; Oprea, O; Nicoara, A; Trusca, R; Radu, M; Neacsu, I. A.; Ficai, D.; Ficai, A.; and Andronescu, E.; "Multifunctional Platforms Based on Graphene Oxide and Natural Products" Medicina (Kaunas), 2019. 55, 6, 2019, doi: 10.3390/medicina55060230.

43. Mahanta, AK; Patel, D.K.; Maiti, P. Nanohybrid Scaffold of Chitosan and Functionalized Graphene Oxide for Controlled Drug Delivery and Bone Regeneration. ACS Biomaterials Science \& Engineering 2019, 5, 51395149, https://doi.org/10.1021/acsbiomaterials.9b00829.

44. Nicoara, I. A.; Neacsu, V. L.; Ene, Vasile, BS; Ficai, A; and E. Andronescu, Hydroxyapatite/Carbon Based Biocomposite Scaffolds as Prospective Materials for Bone Tissue Engineering. UPB Sci. Bull. Ser. B Chem. Mater. Sci, 2019, 81, 107-120, ISSN: 1454-2331, WOS:000501994100011

45. Raslan, A.; Saenz del Burgo, L.; Ciriza, J.; Pedraz, J.L. Graphene oxide and reduced graphene oxide-based scaffolds in regenerative medicine. Int. J. Pharm. 2020, 580, 119226, https://doi.org/10.1016/j.ijpharm.2020.119226.

46. Heidari, M.; Bahrami, S.H.; Ranjbar-Mohammadi, M.; Milan, P.B. Smart electrospun nanofibers containing PCL/gelatin/graphene oxide for application in nerve tissue engineering. Materials Science and Engineering: C 2019, 103, 109768, https://doi.org/10.1016/j.msec.2019.109768.

47. Zhou, M.; Lozano, N.; Wychowaniec, J.K.; Hodgkinson, T.; Richardson, S.M.; Kostarelos, K.; Hoyland, J.A. Graphene oxide: A growth factor delivery carrier to enhance chondrogenic differentiation of human mesenchymal stem cells in 3D hydrogels. Acta Biomater. 2019, 96, 271-280, https://doi.org/10.1016/j.actbio.2019.07.027.

48. Sun, X.; Liu, Z.; Welsher, K.; Robinson, J.T.; Goodwin, A.; Zaric, S.; Dai, H. Nano-graphene oxide for cellular imaging and drug delivery. Nano Research 2008, 1, 203-212, https://doi.org/10.1007/s12274-0088021-8.

49. Zhang, L.; Xia, J.; Zhao, Q.; Liu, L.; Zhang, Z. Functional Graphene Oxide as a Nanocarrier for Controlled 
Loading and Targeted Delivery of Mixed Anticancer Drugs. Small 2010, 6, 537-544, https://doi.org/10.1002/smll.200901680.

50. Anirudhan, T.S.; Chithra Sekhar, V.; Athira, V.S. Graphene oxide based functionalized chitosan polyelectrolyte nanocomposite for targeted and $\mathrm{pH}$ responsive drug delivery. Int. J. Biol. Macromol. 2020, 150, 468-479, https://doi.org/10.1016/j.ijbiomac.2020.02.053.

51. Qi, Z.; Shi, J.; Zhang, Z.; Cao, Y.; Li, J.; Cao, S. PEGylated graphene oxide-capped gold nanorods/silica nanoparticles as multifunctional drug delivery platform with enhanced near-infrared responsiveness. Materials Science and Engineering: C 2019, 104, 109889, https://doi.org/10.1016/j.msec.2019.109889.

52. Mahdavi, M.; Rahmani, F.; Nouranian, S. Molecular simulation of pH-dependent diffusion, loading, and release of doxorubicin in graphene and graphene oxide drug delivery systems. Journal of Materials Chemistry B 2016, 4, 7441-7451, https://doi.org/10.1039/C6TB00746E.

53. Trusek, A.; Kijak, E.; Granicka, L. Graphene oxide as a potential drug carrier - Chemical carrier activation, drug attachment and its enzymatic controlled release. Materials Science and Engineering: C 2020, 116, 111240, https://doi.org/10.1016/j.msec.2020.111240.

54. Wang, P.; Huang, C.; Xing, Y.; Fang, W.; Ren, J.; Yu, H.; Wang, G. NIR-Light- and pH-Responsive Graphene Oxide Hybrid Cyclodextrin-Based Supramolecular Hydrogels. Langmuir 2019, 35, 1021-1031, https://doi.org/10.1021/acs.langmuir.8b03689.

55. Weaver, C.L.; LaRosa, JM; Luo, X.; Cui, X.T. Electrically Controlled Drug Delivery from Graphene Oxide Nanocomposite Films. ACS Nano 2014, 8, 1834-1843, https://doi.org/10.1021/nn406223e.

56. Wen, H.; Dong, C.; Dong, H.; Shen, A.; Xia, W.; Cai, X.; Song, Y.; Li, X.; Li, Y.; Shi, D. Engineered RedoxResponsive PEG Detachment Mechanism in PEGylated Nano-Graphene Oxide for Intracellular Drug Delivery. Small 2012, 8, 760-769, https://doi.org/10.1002/smll.201101613.

57. Ma, X.; Tao, H.; Yang, K.; Feng, L.; Cheng, L.; Shi, X.; Li, Y.; Guo, L.; Liu, Z. A functionalized graphene oxide-iron oxide nanocomposite for magnetically targeted drug delivery, photothermal therapy, and magnetic resonance imaging. Nano Research 2012, 5, 199-212, https://doi.org/10.1007/s12274-012-0200-y.

57. Cheng, S.-J.; Chiu, H.-Y.; Kumar, P.V.; Hsieh, K.Y.; Yang, J.-W.; Lin, Y.-R.; Shen, Y.-C.; Chen, G.-Y. Simultaneous drug delivery and cellular imaging using graphene oxide. Biomaterials Science 2018, 6, 813819, https://doi.org/10.1039/C7BM01192J.

58. Chen, Y.; Yang, Y.; Xian, Y.; Singh, P.; Feng, J.; Cui, S.; Carrier, A.; Oakes, K.; Luan, T.; Zhang, X. Multifunctional Graphene-Oxide-Reinforced Dissolvable Polymeric Microneedles for Transdermal Drug Delivery. ACS Applied Materials \& Interfaces 2020, 12, 352-360, https://doi.org/10.1021/acsami.9b19518.

59. Campbell, E.; Hasan, M.T.; Pho, C.; Callaghan, K.; Akkaraju, G.R.; Naumov, A.V. Graphene Oxide as a Multifunctional Platform for Intracellular Delivery, Imaging, and Cancer Sensing. Sci. Rep. 2019, 9, 416, https://doi.org/10.1038/s41598-018-36617-4.

60. Martín, C.; Ruiz, A.; Keshavan, S.; Reina, G.; Murera, D.; Nishina, Y.; Fadeel, B.; Bianco, A. A Biodegradable Multifunctional Graphene Oxide Platform for Targeted Cancer Therapy. Adv. Funct. Mater. 2019, 29, 1901761, https://doi.org/10.1002/adfm.201901761.

61. Vinothini, K.; Rajendran, NK.; Munusamy, M.A.; Alarfaj, A.A.; Rajan, M. Development of biotin molecule targeted cancer cell drug delivery of doxorubicin loaded $\kappa$-carrageenan grafted graphene oxide nanocarrier. Materials Science and Engineering: C 2019, 100, 676-687, https://doi.org/10.1016/j.msec.2019.03.011.

62. Tiwari, H.; Karki, N.; Pal, M.; Basak, S.; Verma, R.K.; Bal, R.; Kandpal, N.D.; Bisht, G.; Sahoo, NG. Functionalized graphene oxide as a nanocarrier for dual drug delivery applications: The synergistic effect of quercetin and gefitinib against ovarian cancer cells. Colloids Surf. B. Biointerfaces 2019, 178, 452-459, https://doi.org/10.1016/j.colsurfb.2019.03.037.

63. Jafari, Z.; Rad, A.S.; Baharfar, R.; Asghari, S.; Esfahani, MR Synthesis and application of chitosan/tripolyphosphate/graphene oxide hydrogel as a new drug delivery system for Sumatriptan Succinate. J. Mol. Liq. 2020, 315, 113835, https://doi.org/10.1016/j.molliq.2020.113835.

64. Zaboli, M.; Raissi, H.; Moghaddam, N.R.; Farzad, F. Probing the adsorption and release mechanisms of cytarabine anticancer drug on/from dopamine functionalized graphene oxide as a highly efficient drug delivery system. J. Mol. Liq. 2020, 301, 112458, https://doi.org/10.1016/j.molliq.2020.112458.

65. Abdelhamid, HN; Khan, M.S.; Wu, H.-F.F. Design, characterization and applications of new ionic liquid matrices for multifunctional analysis of biomolecules: a novel strategy for pathogenic bacteria biosensing. Anal. Chim. Acta 2014, 823, 51-60, https://doi.org/10.1016/j.aca.2014.03.026.

66. Hussein, K.H.; Park, K.-M.; Kang, K.-S.; Woo, H.-M. Biocompatibility evaluation of tissue-engineered decellularized scaffolds for biomedical application. Materials Science and Engineering: C 2016, 67, 766778, https://doi.org/10.1016/j.msec.2016.05.068.

67. Abdelhamid, H.N.; Wu, H.-F. Reduced graphene oxide conjugate thymine as a new probe for ultrasensitive and selective fluorometric determination of mercury(II) ions. Microchimica Acta 2015, 182, 1609-1617, https://doi.org/10.1007/s00604-015-1461-4.

68. Hummers, WS; Offeman, R.E. Preparation of Graphitic Oxide. J. Am. Chem. Soc. 1958, 80, 1339-1339, https://doi.org/10.1021/ja01539a017.

69. Khalil, I.; Julkapli, N.M.; Yehye, W.A.; Basirun, W.J.; Bhargava, S.K. Graphene-Gold Nanoparticles Hybrid-Synthesis, Functionalization, and Application in a Electrochemical and Surface-Enhanced Raman 
Scattering Biosensor. Materials 2016, 9, https://doi.org/10.3390/ma9060406.

70. Kim, H.; Lee, D.; Kim, J.; Kim, T.-i.; Kim, W.J. Photothermally Triggered Cytosolic Drug Delivery via Endosome Disruption Using a Functionalized Reduced Graphene Oxide. ACS Nano 2013, 7, 6735-6746, https://doi.org/10.1021/nn403096s.

71. Elkhayat, H. Sewing needle penetration into the heart in an infant. Turkish J. Thorac. Cardiovasc. Surg. 2013, 21, 836-838, doi:10.5606/tgkdc.dergisi.2013.5923.

72. Yousef, H.A.; Hamdan, A.E.S.; Elminshawy, A.; Mohammed, N.A.A.; Ibrahim, A.S. Corrected calculation of the overestimated ejection fraction in valvular heart disease by phase-contrast cardiac magnetic resonance imaging for better prediction of patient morbidity. Egypt. J. Radiol. Nucl. Med. 2020, 51, 11, doi:10.1186/s43055-019-0130-8.

73. Allah, E.A.; Kamel, E.Z.; Osman, H.M.; Abd-Elshafy, S.K.; Nabil, F.; Elmelegy, T.T.H.; Elkhayat, H.; Ibrahim, A.S.; Minshawy, A. Al Could Short-Term Perioperative High-Dose Atorvastatin Offer Antiarrhythmic and Cardio-Protective Effects in Rheumatic Valve Replacement Surgery? J. Cardiothorac. Vasc. Anesth. 2019, 33, 3340-3347, doi:10.1053/j.jvca.2019.05.013.

74. Abd El-Hakeem, E.E.; Mohamed, M.S.; Ali, S.M.; El-Minshawy, A.M. Haemodynamic and pulmonary shunt fraction changes with sevoflurane or propofol anaesthesia during one-lung ventilation for thoracic surgery. Egypt. J. Anaesth. 2003, 19, 233-241. 